Dr NENAD Ž. PETROVIĆ, naučni saradnik Institut za strategijska istraživanja

UDK 327(497.1:560)"1980/1982"

Beograd, Neznanog junaka 38

355.02(497.1:560)"1980/1982"

\title{
JUGOSLOVENSKO-TURSKI VOJNI I POLITIČKI ODNOSI 1980-1982
}

\begin{abstract}
APSTRAKT: Jugoslavija i Turska prolazile su kroz krizno razdoblje u istom vremenu. Iako bitno drugačije po društvenom i ekonomskom uređenju kao i prema dubini krize, one su nalazile interes da blisko sarađuju po mnogim pitanjima. Zbog pretnje dezintegracije zemlje i rasplamsavanja građanskog rata, turska vojska je septembra 1980. izvršila udar smenivši civilnu upravu. Tokom posete generala Kenana Evrena Jugoslaviji septembra 1982. iskazani su bliski stavovi o najvećem broju medunarodnih pitanja, ali je ostala razlika u gledanju na problem podeljenosti Kipra gde je SFRJ zadržala stanovište o jedinstvenom Kipru. Usled nedostatka dokumenata iz Vojnog arhiva kao i mogućeg jednostranog gledišta samo na osnovu dokumenata iz Arhiva Ministarstva spoljnih poslova, ovaj rad nije mogao da izrekne odredenije sudove 0 armijskoj saradnji dve vojske u razmatranom periodu.
\end{abstract}

Ključne reči: Jugoslavija, Turska, vojna saradnja, NATO

Odnosi FNRJ i Turske Republike posle Drugog svetskog rata bili su do 1953. godine uglavnom ograničeni na uspostavljanje trgovinskih veza. Do unapređenja dolazi krajem 1950. novim trgovinskim i platnim sporazumom kojim je utvrđena robna razmena od 6,5 miliona američkih dolara $\mathrm{u}$ oba pravca. Do 1953. vidno su prošireni odnosi. Posebno je bio važan interventan uvoz pšenice iz Turske 1952. godine u uslovima blokade sa Istoka i odugovlačenja kreditnih aranžmana sa Zapada. Tada je rešenje pronađeno u uvozu žita iz Turske, pa je tako te godine uvoz iz ove zemlje višestruko premašio izvoz $u$ nju. ${ }^{1} \mathrm{U}$ jugoslovenskom izvozu Turska je sa četvrtog

${ }^{1}$ Sporazumom je regulisano plaćanje 150.000 tona pšenice kupljene u Turskoj. Kupovina se vršila preko T. C. Merkez Bankasi koja je otvorila poseban račun u korist Narodne banke FNRJ do iznosa protivrednosti 100.000 tona pšenice. Kamata je iznosila 3\% godišnje. Trebalo je da kredit bude isplaćen protivvrednošću robe izvezene iz Jugoslavije u Tursku. U članovima 4 i 5 utvrđena je lista ovih proizvoda: drvna građa, cement, hemijski 
mesta u 1953. izbila na drugo mesto u prvom polugodištu 1954. godine, a takođe se Turska u jugoslovenskom uvozu popela $\mathrm{u}$ istom periodu sa osmog na treće mesto. Došlo je i do brojnih političkih susreta. Vraćajući posetu, jugoslovenski ministar inostranih poslova Koča Popović boravio je u Turskoj od 26. februara do 4. marta 1953. Tom prilikom je u Ankari 28. februara potpisan trojni Ugovor o prijateljstvu i saradnji (Turska, Grčka, Jugoslavija), tzv. Balkanski pakt. Kao njegova posledica došlo je do niza međusobnih poseta državnika, do vojne saradnje i povišenja robne razmene. Tako je predsednik Josip Broz Tito posetio Tursku od 12. do 19. aprila 1954.

Na Bledu je 9. avgusta 1954. potpisan novi sporazum tri balkanske države - Ugovor o savezu, političkoj saradnji i uzajamnoj pomoći (Balkanski savez). Premijer i ministar inostranih poslova Turske Adnan Menderes posetio je Jugoslaviju maja 1955.

Pogoršanje odnosa Turske sa Grčkom, septembra iste godine, nije se odrazilo na dobre odnose Beograda sa Ankarom. Tokom 1956. godine dve zemlje postigle su sporazum o obeštećenju turskih dobara, prava i interesa nacionalizovanih u Jugoslaviji. U 1957. odnosi su stagnirali, da bi 1958. godine zahladneli. Do toga je došlo dobrim delom zbog jugoslovenskog stava prema problemu Kipra, koji nije bio dobro primljen u Ankari. Balkanski savez se takođe pokazao nefunkcionalnim i u praksi nije zaživeo. ${ }^{2}$ Tokom 50-ih godina iz Jugoslavije, najviše iz Makedonije i sa Kosova i Metohije,

proizvodi, razne mašine, staklo, emajlirano posuđe, pamučne tkanine i drugo. Sporazum je potpisan u Ankari 16. avgusta 1952. - Službeni list FNRJ, dodatak: Međunarodni ugovori i drugi sporazumi, god. I, br. 5, Beograd, 12. avgust 1953, 2-6.

2 „Tursko-jugoslovenski odnosi“, Enciklopedija Jugoslavije, prvo izdanje, 8, Zagreb 1971, 397-398 (uz deo odrednice koji se bavi odnosima dve zemlje 1945-1970. Enciklopedija ne navodi bilo kakvu literaturu!). O međusobnim odnosima videti još: Balkanski pakt 1953/1954, zbornik dokumenata, Beograd 2005; Balkanski pakt 1953/1954, zbornik radova, Beograd 2008; Dragan Bogetić, Jugoslavija i Zapad 1952-1955: Jugoslovensko približavanje NATO-u, Beograd 2000; Dragan Bogetić, Nova strategija jugoslovenske spoljne politike 19561961, Beograd 2006; Ratomir Milikić, Nekoliko pitanja jugoslovensko-turske saradnje, Spoljna politika Jugoslavije 1950-1961, zbornik, Beograd 2008, 617-627 (za podatke o uvozu-izvozu i uopšte o privrednoj i kulturnoj saradnji). Oskudni su podaci koje je Jugoslovenska narodna armija posedovala o Turskoj uopšte, kao i o njenoj armiji pre 1953. godine. Pronašli smo dve brošure internog karaktera, jednu iz 1947. a drugu iz 1952. Obe sadrže u prilogu skice, mape, spiskove i dr. U starijoj brošuri na ukupno 264 strane detaljnije je opisana tadašnja Turska (počevši od geografskih i demografskih preko istorijskih i kulturnih sve do podataka o armiji), dok je u drugoj koja je nastala u trenutku pristupanja Turske NATO pažnja usmerena samo na turske oružane snage i američku pomoć. Obe brošure pretrpele su ideološko nasilje: u prvoj se daju političke ocene sa pozicija jugoslovenskog savezništva sa SSSR-om, a u potonjoj sasvim se drugačije odnosno pozitivno ocenjuje turska proamerička a samim tim protivsovjetska vojna orijentacija. - Arhiv Vojnoistorijskog instituta u Beogradu (AVII), arhivski broj 2895, fascikla II, redni broj 7 (1947.); arhivski broj 2900, fascikla I, redni broj 4 (1952.) 
prema dogovoru dve vlade dobrovoljno se iselio veći broj pripadnika turske zajednice $\mathrm{u}$ Tursku.

Posle Drugog svetskog rata Turska je umnogome izmenila spoljnu politiku u odnosu na vreme prvog predsednika Mustafe Kemala Ataturka. Dok je politika utemeljivača Republike bila striktna neutralnost, uz održavanje prijateljskih veza sa SSSR-om, dotle je već krajem rata turska upravljačka elita počela da se približava najpre Velikoj Britaniji pa potom i SAD. Već 1945. godine Turska je otkazala ugovor o prijateljstvu koji je imala iz vremena Ataturka sa Sovjetskim Savezom. To je predstavljao korak ka pristupanju NATO. Novostvorena Demokratska partija, nastala izdvajanjem grupe političara iz do tada vladajuće Ataturkove Narodne republikanske partije, pobedila je na izborima 1950. godine i izvršila spoljnopolitički zaokret. Demokratska partija je vladala do maja 1960, kada je u vojnom udaru zbačena sa vlasti i zabranjena. Ipak, spoljnopolitička orijentacija Turske nije se bitno promenila ni posle puča. Ovo je bio tek prvi u nizu vojnih udara koji su zadesili Tursku posle 1945. godine. ${ }^{3}$

Drugi državni udar izvela je armija 1971. godine, a treći i poslednji izvršen je 12. septembra 1980. i o njemu će u ovom članku biti više reči kao o pozadini na kojoj su se prelamali odnosi dve države i armije u turbulentnim vremenima za SFRJ. U godini koja je prethodila udaru i do septembra Republika Turska prolazila je kroz ogromne poteškoće, kako ekonomske a još više političke. Svakodnevno je ginulo u proseku po dvadesetak što civila što policajaca u raznim sukobima krajnje levice i desnice, verskih zanesenjaka, separatističkih pokreta... O tome svedoče i izveštaji koje je ambasada SFRJ slala u Savezni sekretarijat za inostrane poslove. ${ }^{4}$ Još 27. decembra 1979. načelnik Generalštaba general Kenan Evren je zajedno sa komandantima sva četiri roda armije (kopnene vojske, avijacije, mornarice i žandarmerije), predao predsedniku Turske Republike memorandum u kojem se energično zahteva od svih partija i institucija sistema da objedine snage $u$ borbi protiv terorizma i separatizma. ${ }^{5}$ Uprkos verbalnom saglašavanju o potrebi smirivanja situacije u zemlji i rešavanja nagomilanih problema, sve je ostalo po starom - korumpirane stranke i dalje su se borile oko vlasti i preganjale, Skupština nije mogla da donosi zakone a nestašice hrane, električne energije i drugih artikala pogoršavale su stanje. Brojni radnički štraj-

${ }^{3}$ „Turska“, Vojna enciklopedija, drugo izdanje, 10, Beograd 1975, 185.

4 Tako i izveštaj od 22. marta 1980. u kome se razmatraju unutrašnji i spoljni ekonomski odnosi i kretanja (Arhiv Ministarstva inostranih poslova Srbije, Politička arhiva (A MIP - PA), Turska, 1980, fascikla 132, dosije 2, pov. br. 417013, str. 1-9).

${ }^{5}$ A MIP - PA, Turska, 1980, f. 132, d. 6, br. 4517. U depeši je navedeno kako je predsednik Koruturk tek 2. januara preneo liderima dve najveće stranke u Turskoj, Demirelu na vlasti i Bulentu Edževitu u opoziciji, zahteve vojnog vrha. Šefovi manjih partija, od kojih su neki bili u vladajućoj koaliciji, nisu pozvani kod predsednika ovim povodom. 
kovi, zaposedanja fabrika i čitavih gradova u koje policija nije smela da uđe postali su stvarnost Turske tokom 1979. i 1980. godine. Ultradesničari su ubijali komuniste i sindikaliste, a anarhisti su ubijali turske fašiste i konzervativne političare. $\mathrm{O}$ rapidnom pogoršavanju političke i ekonomske situacije svedoči niz službenih telegrama poslatih iz Ankare i Istanbula. ${ }^{6}$

Vojni udar je izvršen u zoru 12. septembra 1980. i protekao je bez žrtava. Na čelu puča bio je načelnik Generalštaba general Evren sa komandantima svih rodova vojske. ${ }^{7}$ Zbačena je vlada, raspuštena skupština, zabranjen rad svih partija, a „lista uhapšenih političara je dosta široka“. Demirel i Edževit su internirani na Galipolju, dok su vođe dve manje stranke iz svrgnute vladine koalicije Erbakan (islamista) i Turkeš (fašista) internirani na neimenovanom ostrvu kod Izmira. Narod je zbog demoralisanosti dugotrajnim neredima i ubijanjima primio puč sa odobravanjem. ${ }^{8}$ Tri dana po svršenom činu, svakako na osnovu informacija iz Ankare i drugih centara, SSIP je sastavio opsežnu Informaciju povodom državnog udara izvršenog u Turskoj. ${ }^{9}$ U tekstu je šire objašnjeno političko stanje koje je uslovilo intervenciju vojske. Vanredno stanje je već bilo na snazi na trećini teritorije Turske, a

${ }^{6}$ A MIP - PA, Turska, 1980, f. 132, d. 6, pov. br. 49965; pov. br. 440642; pov. br. 442656. U depeši br. 49965 od 15. februara 1980. izveštava se da policija upada u fabrike tražeći oružje, da radnici grade barikade koje vojska i policija ruše bornim kolima i tenkovima, da u Izmiru, Eskišehiru i Ankari grupe radnika i seljaka upadaju u magacine i uzimaju hranu „govoreći da radni ljudi u t. (Turskoj - N. P.) danas nemaju čime da plaćaju čak ni hleb. (...) Desničarski teroristi širom zemlje ubijaju istaknute progresivne političare a 'levi' teroristi idu na masovnije i spekularnije (spektakularnije - N. P.) akcije napadajući policijske stanice, policijska kola, sedište Turkešove profašističke partije i Demirelove Partije pravde, benzinske stanice i dr."

${ }^{7}$ Prvu informaciju o zbivanjima poslala je ambasada iz Ankare u 11 časova po lokalnom vremenu, odnosno 10 po srednjoevropskom (A MIP - PA, Turska, 1980, f. 132, d. 7, br. 449453). Sledeću informaciju ambasada je uputila uveče, izveštavajući da je u 13 časova po lokalnom vremenu u televizijskom obraćanju čitava vojna hunta obrazložila svoj postupak. Generali su akcentirali haotično stanje u većini turskih okruga gde je za prethodne dve godine ubijeno više od 5.000 ljudi. Razbijeno je jedinstvo i povampirile su se verske fanatične organizacije koje vuku zemlju u protivnom smeru od sekularnih osnova koje je postavio Kemal Ataturk. Za prethodnih osam meseci Skupština nije mogla da usvoji nijedan zakon niti da izabere predsednika Republike. Kao najveća zla generali su istakli komunizam, fašizam, verski fanatizam i razne separatizme. Obećali su da u spoljnoj politici neće biti promena i naglasili privrženost NATO. U telegramu se kaže da je u 17 časova u turskom MIP-u održan niz sastanaka sa akreditovanim diplomatama gde je elaboriran izvršeni puč. Što se tiče odnosa sa Jugoslavijom sagovornik ambasadora je visoko ocenio jugoslovensku politiku „ali nije propustio da istakne da su od Jugoslavije očekivali veće razumevanje po pitanju Kipra. Dodao da buduće uređenje Kipra oni vide slični (SIC) federalnom uređenju Jugoslavije." - Isto, br. 449537, str. 2.

${ }^{8}$ Isto, br. 449742. - Redžep Taip Erbakan je danas predsednik vlade Republike Turske.

\footnotetext{
${ }^{9}$ Isto, d. 6 , br. 449114 , str. $1-7$.
} 
sada je prošireno na celu zemlju. Udar je prošao bez prolivanja krvi. Opisujući pozadinu svega bacalo se svetlo na razvoj događaja počevši od prošlogodišnjih oktobarskih izbora na kojima je vlada Narodne republikanske partije Bulenta Edževita poražena posle samo 22 meseca provedena na vlasti. To vreme je označeno nastojanjem da se NRP po svaku cenu održi, praćeno vladinom neuspelom ekonomskom politikom. „Onaj deo napora koji je bio usredsređen na stvaranje makar i skromnog privrednog rasta i stabilnosti nacionalne ekonomije zbog otvorene sabotaže krupnog kapitala, izuzetno visoke devalvacije i još većeg porasta cena, doprineli su potpunom promašaju preduzetih mera. Istovremeno, terorizam je upravo besneo. Oružani obračuni levice i desnice, naročito na univerzitetima, bili su česti i krvavi. “10 Nova vlada Sulejmana Demirela, vođe Partije pravde, mnogo je obećavala posebno u pogledu razračunavanja sa terorizmom i rešenjem ekonomske krize. Sve se, međutim, svelo na dovođenje podobnih stranačkih kadrova i „čišćenje“ državne službe od nepodobnih: „Za nepunih pet meseci izbačeno je iz službe preko 10 hiljada naprednih učitelja i nastavnika. (...) Inflacija je prešla $80 \%$, broj nezaposlenih je stalno rastao (oko 3 miliona), dugovanja inostranstvu zbog nepovoljnih kreditnih uslova i rokova prešla su 25 milijardi dolara. Obećana i očekivana pomoć savezničkih država, pre svega SAD i SRN nije ni izdaleka bila dovoljna da doprinese bar delimičnoj sanaciji ekonomske situacije. (...) Sve češće su bile pojave pljačkanja prodavnica namirnica, jer je sve više ljudi ostalo bez osnovnih sredstava za život. " ${ }^{11}$

Posebnu pažnju ova informacija obraća na tursku levicu, osuđujući njene greške. Procenjivalo se da je ona slaba i razjedinjena „pocepana na nekoliko političkih partija (ukupna snaga oko 3\%, nemaju predstavnika u parlamentu) i veliki broj grupa i frakcija, umesto da se u svojim programima više pozabavi situacijom u zemlji, teškoćama sa kojima je suočena radnička klasa i seljaštvo, češće istupa kao zagovornik stranih partija i država što ih je kompromitovalo i rezultiralo nepoverenjem masa i prema tim partijama." 12 Ovu nerešenu situaciju, praćenom haotičnim stanjem i štrajkovima u brojnim vilajetima, iskoristile su dve manje stranke koje su stekle kapacitet za ucenjivanje vlade kao ,jezičak na vagi“ za obezbeđivanje većine u Skupštini: Erbakanova Stranka nacionalnog spasa, zagovornik prelaza na islamističku državu i Turkešova Stranka nacionalističke akcije, čija je politika bila fašistička. U Nacionalni savet za bezbednost (hunta) ušli su osim predsedavajućeg generala Evrena i komandanti ostalih rodova vojske. Turska vojska je od osnivanja Republike igrala veoma važnu ulogu u politici zemlje. Oružane snage broje 570.000 vojnika i savremeno su opremljene. Od osni-

\footnotetext{
${ }^{10}$ Isto, str. 2 .

${ }^{11}$ Isto, 3-4.

${ }^{12}$ Isto, 4.
} 
vača Republike generala Mustafe Kemala svi dotadašnji predsednici bili su vojna lica, aktivna ili bivša. Osim pučeva 1960. i 1971. godine vojska je još 1962. i 1963. pokušavala da izvrši udare, ali bezuspešno. Vojska se do tada nije duže zadržavala na vlasti, ali se u tekstu procenjivalo da će ovoga puta ostati duži period. Armija će, kako se predviđalo, izmeniti Ustav i onemogućiti partije da parališu rad parlamenta. Na kraju izveštaja insinuirala se strana umešanost u puč - komandant vazduhoplovstva general Tahsin Satinkaj uoči udara stigao je iz SAD, a sve je koincidiralo i sa početkom vojnih vežbi NATO u zapadnoj Turskoj.

Istoga dana kada je iz SSIP-a potekla navedena informacija, ambasada Republike Turske u Beogradu uputila je notifikaciju na engleskom jeziku kojom obaveštava Savezni sekretarijat da je Njegova ekselencija general Kenan Evren preuzeo dužnost šefa države i da mu puna titula glasi: Head of State, Chief of General Staff and President of the National Security Council of the Republic of Turkey. ${ }^{13}$

U 1981. godinu obe države stupile su sa nerešenim problemima. Ekonomska situacija u SFRJ bila je, bez obzira na sistemske razlike, slična: inflacija je iznosila 40\%, spoljni dug dostigao je 20 milijardi dolara. Vojna hunta u Turskoj, naročito posle demonstracija na Kosovu marta - aprila 1981. i zahteva za priznanjem samoopredeljenja Albanaca na Kosovu ( $u$ smislu dobijanja republike u SFRJ), kao da je počela nekim krugovima u Beogradu da izgleda kao uzor za rešenje domaćih problema. Ovo posebno posle državnog udara koji je general Vojteh Jaruzelski izvršio u Poljskoj decembra 1981. pred pretnjom narastajućeg pokreta Solidarnost. U tom svetlu razumemo pojačanu vojnu saradnju do koje je došlo u tim godinama između Jugoslavije i Turske. Teško je razlučiti političke od vojnih odnosa koje vodi zemlja kojom vladaju generali, ali ćemo na stranicama koje slede pokušati da razgraničimo čisto vojne od političkih odnosa.

\section{Politički odnosi}

U jednom pregledu bilateralnih odnosa za 1980. godinu navode se značajnije posete: premijer Demirel boravio je u Beogradu na sahrani Tita, ali je na ovoj političkoj manifestaciji bio i tadašnji lider opozicije Edževit. Predsednik Saveznog izvršnog veća Veselin Đuranović se nekoliko puta u proputovanju kroz Tursku kratko sastajao sa domaćim zvaničnicima. Privredni odnosi, uprkos nestabilnosti u Turskoj, održani su na zadovoljavajućem nivou. Kulturna saradnja se dobro odvijala. Turska štampa je, uz nekoliko malicioznih tekstova, objektivno i prijateljski izveštavala o Jugoslaviji.

\footnotetext{
${ }^{13}$ Isto, pov. br. 449952.
} 
Od dolaska hunte na vlast bilateralni odnosi nisu pretrpeli bitnu promenu. Savezni sekretar za inostrane poslove Josip Vrhovec sastajao se kraće u Njujorku i Madridu sa novim ministrom inostranih poslova Turske Turkmenom. Izveštaj nije predviđao bitnu promenu trenda $u$ odnosima dve zemlje. $^{14}$

Početkom 1981. godine sa ambasadorskog mesta u Ankari smenjen je Ramadan Vranići. ${ }^{15}$ Na njegovo mesto imenovan je Redžep Džiha. Prilikom inauguralne posete šefu turske države novi jugoslovenski ambasador primetio je da general Evren priželjkuje poziv za posetu SFRJ. „To on ne čini samo iz sentimentalnih razloga, nego iz dubokih političkih interesa." "16 Gotovo sinhrono, zamenjen je i turski ambasador $u$ Beogradu pa je na mesto Hikmeta Ozkana došao Galip Balkar. ${ }^{17}$

${ }^{14}$ Isto, 1981, f. 122, d. 2, pov. br. 46866, listovi 20-23.

${ }^{15}$ Isto, f. 123, d. 9, pov. br. 45744. (Oproštajna poseta Vranićija šefu države Evrenu 30. januara 1981). Posle smenjivanja Vranići je obavljao dužnost sudije Saveznog ustavnog suda.

${ }^{16}$ Isto, 423900, str. 1-3, navod sa str. 3. (Predaja akreditiva Džihe šefu države Evrenu 6. maja 1981). („Sentimentalni razlozi“ generala Evrena krili su se u činjenici da su njegovi roditelji poreklom iz Preševa i da je imao rodbinu u Skoplju).

${ }^{17} \mathrm{O}$ tome videti traženje agremana za Balkara (Isto, 1981, f. 123, d. 9, pov. br. 424440. Arh. jedinica sadrži i biografiju novog ambasadora); Oproštajni razgovori Ozkana sa Dobrivojem Vidićem, predsednikom Predsedništva SR Srbije (Isto, pov. br. 435659), sa Miloradom Pešićem, zamenikom saveznog sekretara za inostrane poslove (Isto, pov. br. 435941) i sa Dragoslavom Markovićem, predsednikom Skupštine SFRJ (Isto, pov. br. 437510). Ambasador Galip Balkar ubijen je zajedno sa vozačem u službenom automobilu na putu ka Skupštini SFRJ 8. marta 1983. Dvojica mladića, članova jermenske terorističke organizacije, sačekali su vozilo na raskrsnici Resavske i Bulevara kralja Aleksandra i izvršila atentat. Osim ambasadora i njegovog vozača slučajno je nastradao i jedan jugoslovenski državljanin. Obojica atentatora su ubrzo uhapšeni i potom osuđeni u Okružnom sudu u Beogradu. To je bio jedan u nizu takvih atentata izvršenih od 1973, kada su se aktivirale jermenske nacionalističke i osvetničke organizacije koje su težile uspostavljanju nezavisne Jermenije. O tome videti spisak izvršenih atentata na turske diplomatske predstavnike od januara 1973. do oktobra 1981. u kojem je evidentirano ukupno 56 napada u 15 država. Najviše ih je bilo u Francuskoj - 14, potom u Italiji - 8, Švajcarskoj - 7, SAD - 5. (Isto, 1982, f. 113, d. 6, 413748, str. 1-12). Docnije, tokom 1982. jermenski teroristi izvršili su svoj prvi ali spektakularni napad u samoj Turskoj: 7. avgusta u holu ankarskog aerodroma Esenboga pucali su i bacali ručne bombe na prisutne ubivši 9 a ranivši 72 osobe. Od ubijenih petoro su bili građani, dva policajca, šef policijske ispostave i pomoćnik direktora aerodroma. Jedan atentator je ubijen na mestu, a drugi je uhapšen ranjen. (Isto, 438963, depeša Ambasade SFRJ iz Ankare od 10. avgusta 1982). Jermenske organizacije obraćale su se jugoslovenskim diplomatskokonzularnim predstavnicima u svetu. O tome svedoči dopis Generalnog konzulata SFRJ iz Toronta od 12. avgusta 1981. kojim SSIP-u dostavlja pismo na engleskom jeziku koje je konzulat primio od Jermenske revolucionarne federacije - Omladinske organizacije u Kanadi. U pismu se iznose njeni ciljevi - uspostavljanje nezavisne Jermenije kako je bilo predviđeno mirovnim ugovorom u Sevru od 10. avgusta 1920. potpisanom između sila Antante i Otomanske imperije. Jermenska organizacija je konzulatu dostavila (a ovaj prosledio SSIP-u) i fotokopiju štampanog ugovora iz Sevra - brošuru na engleskom jeziku. (Ovaj mirovni ugo- 
Ubrzo je službeni Beograd odreagovao na Evrenovo „priželjkivanje“ pa su počele pripreme za njegovu posetu. Boravak novog šefa turske države prvobitno je planiran od 18. do 21. januara 1982. odmah po završetku njegove posete Bugarskoj. Zbog nagle bolesti a potom i smrti Evrenove supruge obe posete su odložene. Poseta je ostvarena od 20. do 23. septembra 1982 - gotovo simbolično na drugu godišnjicu dolaska vojske na vlast. U tom međuvremenu diplomatska i konzularna predstavništva Jugoslavije u Turskoj uredno su izveštavala o unutrašnjim (ne)prilikama domaćina. Tako se referisalo o odluci turske vlade da zabrani objavljivanje svih vesti i članaka u kojima se kritikuje političko stanje zemlje i to zbog sve češćih i oštrijih kritika koje su stizale pre svega iz zemalja Evropske zajednice. U zatvorima se, prema domaćim procenama, tada nalazilo oko 70.000 ljudi od čega su 85-90\% levičari. Dok su u početku režima vojne hunte hapšenja bila usmerena prema svim protivnicima reda i poretka, u poslednje vreme je na meti bila isključivo levo orijentisana opozicija. U zatvorima je do tada umrlo najmanje 70 osoba, najvećim delom posle torture ili u štrajkovima glađu. Veći broj je ubijen prilikom hapšenja. Vesti o tome su uprkos strogoj kontroli procurile $u$ javnost $i$ izazvale gnušanje $u$ intelektualnim krugovima, posebno na univerzitetima. Mnogi levo orijentisani intelektualci se kao sumnjivi šalju u udaljena mesta gde su pod strogim nadzorom policije. ${ }^{18}$ Pribirajući mišljenja i procene sa raznih strana došlo se i do nekih pozitivnih pokazatelja vojne vlasti, i to paradoksalno od diplomatskih predstavnika Sovjetskog Saveza. Tako je ambasador Rodionov u razgovoru sa Džihom isticao da je ekonomska situacija bolja nego pre vojnog udara: tržište je snabdeveno dovoljnom količinom neophodnih artikala, inflacija je smanjena sa $100 \% \mathrm{u}$ 1980. na 36\% u 1981. godini, izvoz je u istom periodu porastao za 50\%. Međutim, odnosi sa istočnoevropskim zemljama su zahladili. ${ }^{19}$ Jedan turski novinar, za koga se navodi da je simpatizer Edževita, u razgovoru sa službe-

vor je jedini od potpisanih posle Prvog svetskog rata koji nije stupio na snagu a revidiran je 1923. ugovorom u Lozani). Među potpisnicima ugovora bili su predstavnici Kraljevine Srba, Hrvata i Slovenaca na mirovnoj konferenciji, Nikola Pašić i Ante Trumbić. U pismu jermenske organizacije naglašavalo se da je SFRJ pravni sledbenik Kraljevine SHS (Isto, 1981, f. 122, d. 9 , pov. br. 444960).

${ }^{18}$ Isto, 1982, f. 113, d. 6, 48128, str. 1-3. Izveštaj Generalnog konzulata u Istanbulu od 13. februara 1982. O surovom obračunavanju sa komunistima govori i informacija Generalnog konzulata od 3. septembra 1981. u kojoj se kaže da su organizacije KP Turske dobrim delom likvidirane od strane vojnog režima. Uhapšeno je 1500-2000 aktivnih članova KPT. Iako je režim na početku vanrednog stanja isticao da će podjednako udariti protiv svih protivnika, „tu nema stvarne ravnoteže, jer je borba protiv levice daleko sveobuhvatnija i sistematičnija nego protiv desnice." Režim štedi ultra desnicu Turkešove stranke, a posebno Erbakanove islamiste jer ne želi da se zameri arapskim petrolejskim zemljama. (Isto, 1981, f. 122, d. 18, pov. br. 445273, str. 1-3, navod sa str. 2).

${ }_{19}$ Isto, 1982, f. 113, d. 6, 420360, str. 1-2, Izveštaj od 19. aprila 1982. 
nikom jugoslovenske ambasade Zekovićem izneo je sledeće ocene o stanju vojnog režima: narod koji ne voli diktaturu ipak je zbog mira koji mu je obezbedila lakše podnosi. Zbog toga nema pravog otpora režimu, narod aplaudira na brojnim mitinzima organizovanim širom Turske na kojima govori general Evren. Narodna republikanska partija izgubila je idejno i organizaciono jedinstvo još pre prevrata pocepana na levicu, centar i desnicu. Edževit pokušava da okupi kadrove i članstvo, ali sagovornik procenjuje da bi to mogao postići tek posle 3-4 godine delovanja na slobodi. Demirelova stranka je očuvala strukturu i jedinstvo i ona će se verovatno pod novim nazivom na prvim izborima vratiti na vlast. Ta stranka i nema mnogo problema sa generalskom vladom. Potpredsednik u „činovničkoj vladi“ (koju su pučisti stvorili) Turgut Ozal bio je potpredsednik u Demirelovoj vladi zbačenoj udarom! Demirel i njegovi ljudi imaju podršku krupnog kapitala. Aktuelni režim sprovešće ustavnu reformu kako bi se smanjio broj stranaka u Parlamentu povećanjem izbornog cenzusa, a time će biti olakšan rad zakonodavnog tela (uvođenjem dvopartijskog ili najviše tropartijskog sistema - N. P.). U tom cilju se predviđa zabrana prelazaka poslanika iz jedne $\mathrm{u}$ drugu partiju (ukidanje slobodnog raspolaganja mandatom poslaniku i njegova obaveza da se povinuje partiji koja ga je istakla - N. P.). Time se nameravala sprečiti kupoprodaja poslanika, što je bilo uobičajeno do puča. Bivši partijski lideri neće moći da se kandiduju na prvim izborima, a još nije izvesno da li će im biti omogućeno da formiraju nove partije. ${ }^{20}$

Imajući sve navedeno $u$ vidu, potom ograđivanje od hunte kako EZ tako SR Nemačke, najvažnijeg ekonomskog i političkog partnera Turske na zapadu, deluje iznenađujuće da je SFRJ kao zemlja sa socijalističkim sistemom primila $u$ posetu sa najvišim državnim počastima šefa vojne hunte koji nemilosrdno progoni komuniste i uopšte levicu! Ovo takođe važi i za NR Bugarsku.

General Evren je doputovao u Beograd avionom iz Bugarske. Njegovu balkansku turneju možemo sagledavati i kao diplomatsko nastojanje da se Turska izvuče iz političke izolacije u koju je sve više zapadala budući da je EZ odbijala da joj pruži obećane kredite zbog širokih represija prema političkim oponentima i gušenja ljudskih prava. Tokom trodnevnog boravka visoke turske delegacije, koja je dočekana na najvišem nivou i sa najvišim počastima, generala Evrena primile su jugoslovenske rukovodeće ličnosti kao i nominalni šef države Petar Stambolić, predsednik Predsedništva SFRJ. Specijalni izveštači turskih listova su opširno i afirmativno pisali o poseti. Svi tiražni listovi su izvestili da je general Evren iz Beograda za Skoplje otputovao „plavim vozom“ maršala Tita i da ga je najviše rukovodstvo SR Makedonije srdačno dočekalo. Topao prijem se ponovio u Bitolju. Evren

${ }^{20}$ Isto, 430665, str. 1-3, Izveštaj Ambasade SFRJ od 10. juna 1982. 
je posetio istorijske znamenitosti Skoplja, a u Bitolju zgradu nekadašnje vojne gimnazije u kojoj je učio Ataturk. Između dve zemlje postignuta je načelna saglasnost o proizvodnji oružja u Turskoj po jugoslovenskim licencama, isticao je tiražni Milijet. Radi konačnog dogovora jugoslovenska tehnička delegacija treba da idućeg meseca (oktobra 1982) doputuje u Tursku da bi se ispitale mogućnosti proizvodnje oružja, koje se može plasirati u zemlje Trećeg sveta. Jugoslavija, naglašava list, pokriva sopstvenom proizvodnjom $70 \%$ svojih potreba za oružjem i izvozi u zemlje Trećeg sveta. Jugoslovenska vlada je povećala kvotu za prolazak turskih kamiona na internacionalnim rutama (TIR). ${ }^{21} \mathrm{U}$ mesečnom pregledu pisanja turske štampe za septembar 1982. navodi se izuzetan publicitet dat poseti šefa turske države SFRJ. Od objavljenih 370 tekstova koji su se ticali Jugoslavije, čak 206 je bilo o Evrenovoj poseti. Tiražna i malotiražna štampa uglavnom su pisale objektivno, kaže se u izveštaju. Izdvojena su kao nepovoljna po Jugoslaviju dva teksta, jedan objavljen u kako se navodi senzacionalističkom istanbulskom listu Bulevar a drugi u ankarskom malotiražnom listu Baris. Oba članka se ocenjuju malicioznim, budući da u prvi plan stavljaju nacionalne probleme i trzavice koje su počele sa demonstracijama na Kosovu. Tekstopisci prikazuju SFRJ kao zemlju u kojoj nisu rešeni nacionalni problemi. $^{22}$ I tokom oktobra zabeleženo je pojačano interesovanje turske štampe za Jugoslaviju. ${ }^{23}$

Tokom posete Jugoslaviji najznačajniji je, svakako, bio razgovor šefa turske države Kenana Evrena sa predsednikom Predsedništva SFRJ Petrom Stambolićem. ${ }^{24}$ Sadržina razgovora sumirana je u dopisu razaslanom svim

${ }^{21}$ Isto, d. 38, 444555, str. 1-2, Izveštaj iz Ankare od 23. septembra 1982. - O saradnji dve države i armije u oblasti vojne industrije postoje samo oskudni dokazi koje iznosimo na kraju članka.

${ }^{22}$ Isto, d. 1, 448133, str. 1-3. I turska strana je imala primedbe na izveštavanje jugoslovenskih medija. Tako je ambasador Balkar, zatraživši prijem u SSIP-u, preneo načelniku Prve uprave Iliji Đukiću 20. jula 1982. da je nezadovoljan emisijom prikazanom 6. jula na TV Beograd koja se bavila Sovjetskom Jermenijom. U ovoj reportaži pominjan je i pogrom nad Jermenima u Turskoj 1915. godine i navodila se brojka od 1,5 miliona žrtava. Do sada u Jugoslaviji nije bilo ovakvih emisija, istakao je Balkar, a „turski naučnici pokušavaju objasniti i javno objaviti naučne radove o zbivanjima iz tog vremena," te bi ovakvo pristupanje problemu „moglo i od Jugoslavije vremenom stvoriti plodno tle za terorističke akcije Jermena uperene protiv turskih diplomatskih predstavnika u svetu“. U Jugoslaviji novinari su slobodni u svom radu i jedna emisija ne može predstavljati predtekst za terorizam protiv Turske odgovorio je Đukić. (Isto, d. 10, 436091, str. 1-2, zabeleška o razgovoru)

${ }^{23}$ Isto, d. 1, str. 1-3, Izveštaj iz Ankare od 2. decembra 1982.

${ }^{24} \mathrm{O}$ tome videti belešku o razgovoru Evren - Stambolić zajedno sa neautorizovanim stenogramom (Isto, 1982, f. 113, d. 38, strogo pov. 445023), kao i zajedničko saopštenje o poseti (Isto, d. 37, listovi 566-571). General Evren se sastao i sa predsednicom SIV-a Milkom Planinc i sa predsednikom Predsedništva SR Makedonije Angelom Čemerskim. 
diplomatskim i konzularnim predstavništvima Jugoslavije. ${ }^{25}$ Do trodnevne posete šefa turske države Evrena došlo je na zahtev turske strane; prvi dan posete protekao je u Beogradu, ostala dva u Skoplju i Bitolju. Konstatovana je sličnost u stavovima o većini spoljnopolitičkih problema. Tako su bili podudarni stavovi osude Izraela zbog agresije na Liban (bombardovanje palestinskih izbegličkih logora u Bejrutu) kao i zajednička podrška Palestincima za stvaranje njihove države. ${ }^{26}$ Turska je, međutim, shodno svojoj blokovskoj svrstanosti, po mišljenju jugoslovenskih sagovornika, jednostrano bacala krivicu za zaoštrenost među blokovima isključivo na Sovjetski Savez apostrofirajući ulazak sovjetskih trupa u Avganistan krajem 1979. godine. U istom kontekstu „zamrzavanja detanta“ posmatrala se i intervencija vojske u Poljskoj. Turska strana se izjasnila za balkansku saradnju, bez konkretnog isticanja šta se pod time podrazumevalo. O najvažnijem spoljnopolitičkom pitanju za Tursku vezanom za Kipar i njegovu podeljenost od 1974. godine, dve strane su zadržale oprečne stavove. Osnova spora sa Grčkom, kako je isticao Evren, bilo je to što je ona jednostrano proširila vazdušni prostor kao i područje teritorijalnih voda u Egeju što dovodi do čestih povreda prostora. Papandreu je prekinuo dijalog dve zemlje. Izneli su svoje viđenje istorijata kiparskog problema. Po njima turska zajednica na Kipru morala bi imati garancije za bezbednost zbog loših iskustava u prošlosti sa grčkom većinom na ostrvu. Zbog toga su smatrali da bi neka vrsta „bizonalnosti" (dva entiteta, dve federalne jedinice - N. P.) predstavljala dobro rešenje. Jugoslovenski sagovornici izneli su „naš poznati principijelni stav o Kipru“. ${ }^{27}$ U razgovorima o bilateralnim pitanjima dve strane su se saglasile o proširivanju ekonomske saradnje, Turska je insistirala na saradnji dve policije u suzbijanju kriminala, šverca oružja i narkotika a posebno na

${ }^{25}$ Isto, d. 18, 441216/4, str. 1-3, Dopis Prve uprave SSIP-a od 4. oktobra 1982.Na kraju cirkularnog pisma se navodi da ga svako koristi u zavisnosti od toga ko mu bude sagovornik.

${ }^{26}$ Zbog bombardovanja Bejruta u kojem je bilo velikih civilnih žrtava, Socijalistički savez radnog naroda organizovao je miting solidarnosti sa Palestincima a protiv agresivne politike Izraela, jula 1982. na Trgu Marksa i Engelsa (danas Trg Nikole Pašića) u Beogradu. Tokom mitinga desilo se nekoliko incidenata: grupa arapskih studenata zapalila je lutku sa natpisom Juden na šta milicija nije reagovala; grupa domaćih disidenata iskoristila je miting da razvije transparent sa natpisom Solidarnoszt što je bio logo poljskog pokreta koji je pučem generala Jaruzelskog zabranjen. Time su želeli da iskažu svoju solidarnost sa poljskim pokretom. Milicija je odvukla grupu beogradskih disidenata (Gordan Jovanović, Dragomir Olujić i drugi) u obližnju knjižaru izdavačkog preduzeća Komunist u prizemlju zgrade Borbe i tamo ih pretukla da bi ih kasnije sudija za prekršaje kaznio zatvorskom kaznom. Podaci dobijeni u razgovoru autora sa Jovanovićem i Olujićem.

${ }^{27}$ Isto, d. 18, 441216/4, navod sa str. 2. Iako se u tekstu ne navodi šta bi to bilo, iz neautorizovanog stenograma i iz drugih izvora poznato je da je jugoslovenska politika podržavala grčku stranu u sporu insistirajući na teritorijalnoj celovitosti Kipra i njegovoj nedeljivosti na turski i grčki deo. 
saradnji dve zemlje u suzbijanju svih vidova terorizma. ${ }^{28}$ U zaključku se iznosilo: „Za tursku stranu ova poseta bila (je) izvanredno važna zbog daljeg izlaska vojne vlade na međunarodnu političku scenu, a konkretnije u odnosu na njene balkanske susede. Poseta Skoplju i isticanje ravnopravnog položaja turske nacionalne manjine iskorišteni i kao poruka Bugarskoj i Grčkoj. (...) I za nas, u odnosu na naše susede na Balkanu, poseta i vremenski i sadržajno važna manifestacija naše dobrosusedske politike sa svim partnerima. Njome (smo) postigli i određeni balans u odnosima sa Grčkom i Kiprom i posetama na visokom i najvišem nivou koje (smo) učinili sa tim zemljama. “29

\section{Vojni odnosi ${ }^{30}$}

U zemljama u kojima je vojska na vlasti teško je razlučiti čisto vojne odnose od političkih, pa se to odnosi i na Tursku. SFRJ je, takođe, još od Titovog vremena bila militaristička država sa jakim uticajima vojske na društveni, politički pa čak i kulturni život. JNA je doživljavana kao „zenica oka“, ona je bila „Titova armija“, „narodna armija“, „garant stabilnosti i nacionalne ravnopravnosti“, poslednja odbrana socijalizma i njegovih vrednosti, njeno učešće je bilo nezaobilazno prilikom raznih kulturno-umetničkih svetkovina u čast jubileja Tita, partije, ustanka i revolucije.

SFRJ nije ni formalno protestovala zbog uvođenja vojnog režima $u$ Turskoj već je primila šefa vojne hunte sa najvišim počastima, iako je taj režim najviše progonio levicu. Ovde su tzv. viši državni razlozi prevagli nad moralnim i ideološkim. Međutim, ne samo da je država zbog oportuniteta zadržala dobre odnose sa turskom generalskom upravom već je JNA u ovom periodu ostvarila zavidnu saradnju sa turskom armijom! Odnosi su bili srdačni, izuzimajući jedan pomorski incident do koga je došlo nepažnjom ili neznanjem jugoslovenske strane. Naime, brod Jugoslovenske ratne mornarice Split bez dozvole je ušao u moreuz Dardaneli i Mramorno more. Da je situacija mogla da dovede i do ozbiljnijeg incidenta, govori i to da su turski ratni brodovi bezuspešno signalizirali i pokušavali da zaustave Split. Jugoslovenski brod je okružen turskim patrolnim čamcima sproveden

${ }^{28}$ Isto. Naznačeno je da je turska strana želela da ovo poslednje uđe u kominike o razgovorima ali je domaćin to otklonio. Iz ovoga se može razumeti želja jugoslovenskog vrha da se ne obavezuje na saradnju po pitanju terorizma kao i da se ne svrstava u pogledu jermenskog problema.

${ }_{29}$ Isto, 3.

${ }^{30}$ Ovaj deo teksta je napisan isključivo na osnovu dokumenata nekadašnjeg SSIP-a, budući da Vojni arhiv ima lošu praksu i ne povinuje se opštim zakonskim normama da se dokumenta izdaju istraživačima posle 30 godina od njihovog nastanka već ih drži pod embargom čitavih 50 godina! 
u Čanakale i „da se tu nije zaustavio oni bi otvorili vatru na brod." Brod je u luci zadržan jednu noć pa je pušten da prođe pošto je ambasador Vranići razgovarao u turskom MIP-u. Pomoćnik ministra Kamel izložio mu je tom prilikom „da su oni imali pravo da na takvo ponašanje našeg broda otvore vatru, ali to nisu uradili ceneći prijateljske odnose sa našom zemljom ...". Vranići se izvinio za postupak jugoslovenskog broda objašnjavajući da je reč o zabuni, jer je kapetan verovao da je dozvola za prolazak i toga puta data kako je do tada uvek bio slučaj. ${ }^{31}$

Ambasada Turske u Beogradu obratila se dopisom SSIP-u molbom da se školskom brodu turske ratne mornarice Gazi Hasan paša omogući poseta splitskoj luci. Neslužbena poseta bila bi realizovana u sklopu vežbi koje obavljaju kadeti četvrte godine Mornaričke vojne škole, između 30. jula i 5. avgusta 1981. godine. Ambasada se obraćala vlastima da odobre posetu i obaveste je o svim detaljima (pozdravne salve i sl.). ${ }^{32}$

Kao svojevrsna prethodnica Evrenu, u službenoj poseti SFRJ od 20. do 24. aprila 1981. boravio je general Nuretin Ersin, načelnik Generalštaba i komandant kopnenih snaga Turske. Do posete je došlo na poziv načelnika Generalštaba JNA. Savezni sekretarijat za inostrane poslove predložio je da generala Ersina primi u kurtoaznu posetu i predsednik SIV-a Veselin Đuranović. „Nije praksa da predsednik SIV-a prima šefove vojnih delegacija. Međutim, ovde se radi o specifičnom slučaju. Naime, general Ersin je jedan od 5 članova Saveta nacionalne bezbednosti Turske (vrhovnog tela zemlje) na čijem čelu se nalazi šef države, general Kenan Evren. Prema najnovijem razvoju situacije, svi su izgledi da će armija ostati odlučujući faktor u Turskoj za duži period. Stoga, I Uprava smatra da bi bilo korisno da predsednik SIV-a, Veselin Đuranović, primi generala Ersina. Molimo za stav. “33 Do razgovora Đuranović-Ersin došlo je 24. aprila. U njima je konstatovano pomanjkanje kontakata između dve zemlje kao i potreba osnaživanja saradnje. Ersin se založio za proširenje saradnje dve armije (između vojnih akademija, vojno-privredna saradnja). Đuranović mu je izložio jugoslovenske

${ }^{31}$ Isto, 1980, f. 133, d. 28, 413121, str. 1-3, Depeša Ambasade iz Ankare od 4. marta 1980. Jugoslovenski ambasador je na kraju dopisa zatražio hitnu informaciju iz Beograda o tome kako je došlo do ovakve greške. Iz kabineta saveznog sekretara Vrhovca usledio je zahtev SSNO da pruži odgovor. U ovoj arhivskoj jedinici, međutim, tog odgovora nema.

32 Isto, 1981, f. 123, d. 15, pov. br. 434163, str. 1-2, Dopis od 25. juna 1981. na francuskom jeziku sa propratnim podacima o brodu: tonaža 2540 tona, dužina $99 \mathrm{~m}$, širina $11,8 \mathrm{~m}$, dubina gaza $3,4 \mathrm{~m}$; posadu čine 27 oficira, 52 podoficira, 141 kadet, 94 mornara, 2 civilna službenika. U arhivskoj jedinici nema odgovora na ovaj zahtev.

${ }^{33}$ Isto, pov. br. 418891, Beleška Prve uprave SSIP-a od 13. aprila 1981. upućena kabinetu saveznog sekretara Vrhovca i drugim funkcionerima. Kao i u prethodnim slučajevima zbog zatvorenosti građe Vojnog arhiva nemamo podrobnije podatke o pripremama za ovu posetu, njenim razlozima, kao ni zapisnike sa razgovora Ersina i njegovih domaćina u Generalštabu JNA. 
stavove o međunarodnim pitanjima. Na kraju se predsednik SIV-a osvrnuo i na skorašnje demonstracije na Kosovu, iznevši jugoslovenski stav da je moguće očekivati izvesno zahlađenje odnosa sa Albanijom zbog njene podrške snagama koje su izazvale nerede. Đuranović je takođe iskazao odlučnost da se ostvari program ekonomske stabilizacije. ${ }^{34}$

Još uvek ne možemo pouzdano znati šta je jugoslovenski vojni vrh razgovarao sa generalom Ersinom, ali jedan telegram iz Ankare upućuje na jednu od mogućih tema. Savetnik bivšeg predsednika turske vlade Skopeli (ili Škopelji? - N. P.) u razgovoru sa ambasadorom Džihom savetovao ga je da razgovore sa Ersinom treba iskoristiti da se turskom državnom vrhu objasni jugoslovenska politika nesvrstavanja kao faktor svetskog mira i stabilnosti. „Tursko vojno rukovodstvo niti poznaje suštinu nesvrstanog pokreta, niti njegov značaj, i ovo je izvanredna prilika, da se jednom od najuticajnijih ljudi sadašnje t. (Turske - N. P.) ukaže i objasni ovo. Tursko vojno rukovodstvo je opterećeno vezama sa zapadom, i ono ne vidi stvarni značaj koji n z (nesvrstane zemlje - N. P.) igraju danas u svetu, kao ni što granične zemlje znače za t. T. ne može da vodi balansirajuću politiku i da se isključivo vezuje za jedan blok, a da, sa takvim pokretom, kao što je nesvrstani, ne održava tesne veze i zanemaruje njihovu ulogu u svetu. (...) Sadašnja poseta Ersina j. (Jugoslaviji - N. P.) je izvanredna prilika za to. “35

Do uzvratne posete došlo je od 15. do 19. marta 1982, kada je u Turskoj boravila delegacija Oružanih snaga SFRJ na čelu sa saveznim sekretarom za narodnu odbranu admiralom Brankom Mamulom, što svedoči o visokom nivou saradnje dve armije. Od dokumenata posedujemo samo izveštaj ambasade u kojem se naglašava srdačnost prijema i visok tretman koji je delegacija uživala. Delegaciju su primili načelnik generalštaba Evren, svi članovi Saveta nacionalne bezbednosti, potpredsednik vlade (u odsutnosti predsednika), ministar odbrane i komandanti armija u Izmiru i Istanbulu. U svim razgovorima odnosi dve zemlje ocenjeni su kao veoma dobri. Isticana je težnja za produbljivanje saradnje na svim poljima. „Poseti naše delegacije dat zapažen publicitet. Veliki listovi redovno informisali o toku posete, neki objavljivali dnevno i po dve slike na uvodnim stranicama. Posebnih komentara nije bilo. Televizija svakodnevno objavljivala kraće inserte $u$ okviru večernjeg dnevnika, koji u nekim slučajevima trajali i po četiri minuta. (...) Smatram da je poseta ostvarena u vreme višemesečnog nepostojanja dijaloga na vladinom nivou, te (je) smatramo veoma korisnom. “36

${ }^{34}$ Isto, pov. br. 422928, SSIP - Ambasadi u Ankari dostavlja informaciju sa razgovora Đuranović - Ersin, 5. maja 1981.

${ }^{35}$ Isto, 421963, str. 1-2.

${ }^{36}$ Isto, 1982, f. 113, d. 27, 414867, str. 1-2, Ambasada u Ankari - SSIP-u 26. mart 
Krajem 1982, na osnovu prethodnih obostranih političkih i vojnih poseta, došlo je do konkretnih razgovora o saradnji dve armije na polju vojne industrije. U dokumentu se navodio spisak tema koje su od posebnog interesa za tursku armiju: lako naoružanje i municija za njega, artiljerija i artiljerijska municija, brodogradnja, training devices (sredstva za obuku? N. P.), optička i elektronska industrija, proizvodnja borbenih vozila (armoured vehicles) kao i motora za njih. Na čelu turske delegacije nalazio se general-potpukovnik Sedat Tokgöz, a od preostalih pet članova dvojica su bili vojni inženjeri, jedan vojni hemičar a jedan direktor neke „istraživačke grupe“. Razgovori su bili predviđeni od 13. do 17. decembra 1982. ${ }^{37}$ Poznato je da je SFRJ imala veoma razvijenu industriju naoružanja. U nedostatku vojnih dokumenata možemo samo pretpostavljati, na temelju sastava turske delegacije i spiska njihovih tema od interesa, do kakvih je rezultata dovelo pregovaranje dve strane.

${ }^{37}$ Isto, 2909, str. 1-2, Pismo Ambasade Turske na engleskom jeziku od 6. decembra 1982. bilo je odgovor na traženje podataka iz SSIP-a od 11. novembra. Ovaj dopis nismo pronašli. 
Nenad Petrović

THE YUGOSLAV-TURKISH MILITARY AND POLITICAL RELATIONS 1980-1982

\section{Summary}

Both countries went through the crisis in the period that was covered by the research results of this article. Although different by the political and ideological social order, some of the same challenges led to closer cooperation. After the Turkish Army overtook the political power in 1980, General Kennan Evren visited Yugoslavia in 1982. This visit resulted in most of the similar political standpoints of the both political (military) leadership. Close political understanding was shown, except for the question of the Cyprus. Author pinpointed the problem of the relevant archival sources from the Military Archive in Belgrade. Although the 30 years of the historical distance was established, the relevant archival materials on this subject are still not opened for the researchers. 